Discussion Paper No. 06-084

\title{
Transfer Pricing of Intrafirm Sales as a Profit Shifting Channel - Evidence from German Firm Data
}

Michael Overesch

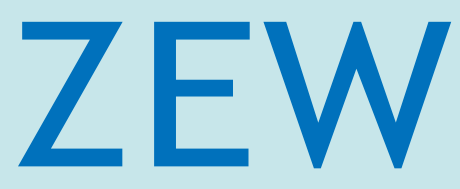

Zentrum für Europäische Wirtschaftsforschung $\mathrm{GmbH}$

Centre for European

Economic Research 
Discussion Paper No. 06-084

\title{
Transfer Pricing of Intrafirm Sales as a Profit Shifting Channel - Evidence from German Firm Data
}

\author{
Michael Overesch
}

Download this ZEW Discussion Paper from our ftp server:

ftp://ftp.zew.de/pub/zew-docs/dp/dp06084.pdf

Die Discussion Papers dienen einer möglichst schnellen Verbreitung von neueren Forschungsarbeiten des ZEW. Die Beiträge liegen in alleiniger Verantwortung der Autoren und stellen nicht notwendigerweise die Meinung des ZEW dar.

Discussion Papers are intended to make results of ZEW research promptly available to other economists in order to encourage discussion and suggestions for revisions. The authors are solely responsible for the contents which do not necessarily represent the opinion of the ZEW. 


\section{Non-Technical Summary}

Multinational companies have enhanced tax planning opportunities by means of crossborder profit shifting. In particular, it is supposed that transfer pricing of intrafirm trade constitutes an important channel for companies to shift taxable profits between jurisdictions. While taxable profits of affiliated companies are determined by separate accounting, it is often impossible to determine a true intrafirm transfer price since economies of integration are special characteristics of affiliated companies. Therefore, it is reasonable that multinationals have a range of opportunities to set tax-optimal transfer-prices, even though transfer prices are audited according to the arm's length principle. This would imply internal management distortions for companies and tax revenue consequences for countries.

This paper investigates whether transfer pricing of intrafirm sales within multinationals represents an important channel of company tax planning. A simple theoretical model, considering transfer pricing of intrafirm sales of a multinational company, is used to obtain empirical implications. The theoretical analysis suggests a negative effect of the local tax rate on transfer prices and the size of intrafirm sales.

The empirical analysis considers directly the supposed tax response of balance sheet items reflecting intrafirm sales. Micro-level panel data of German affiliates in 31 countries during the period from 1996 until 2003 are employed, which are taken from the MiDi database provided by the Deutsche Bundesbank. The empirical results show that the size of balance sheet items, which reflect intrafirm sales, decrease with an increasing local tax rate. Thus, it can be confirmed that profit shifting by means of transfer pricing of intrafirm sales works effectively. The magnitude of estimated tax responses suggests that transfer pricing constitutes an important channel of tax planning despite anti-avoidance legislations and tax audits based on the arm's length principle. 


\title{
Transfer Pricing of Intrafirm Sales as a Profit Shifting Channel - Evidence from German Firm Data
}

\author{
Michael Overesch \\ $(\mathrm{ZEW}) * \ddagger$
}

December 2006

\begin{abstract}
This paper investigates whether transfer pricing of intrafirm sales within multinationals represents an important channel of company tax planning. A simple theoretical model, considering profit shifting activities of a multinational company, is used to obtain empirical implications. The empirical analysis, based on a panel of German multinationals, considers directly the supposed tax response of intrafirm sales. The analysis shows a significantly negative impact of the local tax rate on the size of balance sheet items, which reflect intrafirm sales. Thus, the results suggest that transfer pricing of intrafirm sales constitutes an important channel of companies' profit shifting activities.
\end{abstract}

Keywords: Taxation, Multinationals, Profit Shifting, Transfer Pricing, Firm-level Data

JEL Classification: H25, H26, H32

\footnotetext{
*Address: Centre for European Economic Phone: +49621235 394

Research (ZEW) Fax: $\quad+49621235223$

L 7,1

D-68163 Mannheim $\quad$ E-mail: overesch@zew.de
}

Germany

${ }^{\ddagger}$ The author is grateful to the Deutsche Bundesbank for granting access to the MiDi database, and to Thiess Buettner and Ulrich Schreiber for helpful comments on an earlier draft. Financial support by the German Research Foundation (DFG) is gratefully acknowledged. 


\section{Introduction}

International differences in company taxation not only affect companies' real investment decisions, but also the tax design of investments. It is often assumed that profit shifting via transfer pricing of intrafirm trading constitutes an important way for companies to design tax-optimal real investments. A basic principle in taxation of affiliated companies located in different countries is to determine their taxable profits by separate accounting. Transfer pricing of company-internal trade is usually controlled by the 'arm's length principle'. However, since economies of integration are special characteristics of affiliated companies, it is often impossible to calculate a true intrafirm transfer price. Hence, multinationals should have a range of opportunities to set tax-optimal transfer prices. This would imply distortions of companies' internal management decisions based on transfer prices. Moreover, this would also have tax revenue consequences for countries.

While extended surveys on empirical evidence of companies' behavioral response to taxation are provided e.g. by Hines (1999) and Devereux (2006), let us briefly look at previous studies, which in particular analyse empirically tax planning via transfer pricing. Empirical investigations often attempt to confirm indirectly that profit shifting with regard to transfer pricing works effectively. Typically, reported profits are used as the dependent variable. Grubert and Mutti (1991) as well as Hines and Rice (1994), for example, find a negative relationship between reported profits and the local tax level of US outbound FDI. These results are confirmed by Huizinga and Laeven (2005) for European companies and by Weichenrieder (2006) for German FDI data. Although some studies such as Jacob (1996) considers intrafirm sales as an explaining variable, these results can be taken only as indirect hints that taxable profits are effectively shifted, e.g. by transfer pricing.

However, a more precise identification of transfer pricing as a specific profit shifting channel is feasible by focusing directly on intrafirm deliveries. Then, problematic aspects of indirect 
investigation approaches, which may arise, for example, from competing profit shifting activities such as financing, can be avoided. Up to now only a few studies, which are mostly based on US data, focus directly on data of goods traded. Swenson (2001) finds a small tax response of transfer prices by using product-level trade price data of US imports. Similarly, Clausing (2003) finds, based on product-level price data, that prices of intrafirm trade respond to tax levels, whereas prices of open-market operations are not affected by different tax levels. Furthermore, a few studies use company data of intrafirm transactions. By using aggregated firm data, Clausing (2001, 2006) confirms an impact of taxes on intrafirm trade flows between US firms and their affiliates. Grubert (2003) shows, based on a cross-section analysis of US Treasury data, that the ratio of intrafirm transactions to total sales of US controlled foreign companies is influenced by taxes.

This paper aims to provide additional insights into the tax response of intrafirm sales. The empirical approach focuses directly on balance sheet items reflecting intrafirm sales. The analysis is based on the $M i D i$ database, a comprehensive micro-level panel database of virtually all German multinationals, made available for research by the Deutsche Bundesbank. Under German tax law repatriated profits are almost completely tax exempt. Thus, taxation of the foreign affiliate is decisive for profit shifting. In fact, a significant impact of tax rates on multinational profit shifting activities, by means of intrafirm sales, is confirmed by the following analysis. It can be shown that the size of balance sheet items, which reflect intrafirm sales, decreases with an increasing local tax rate. These results suggest that transfer pricing represents a relevant channel of tax planning.

The paper is structured as follows; in section 2, a theoretical model considers profit shifting decisions of a multinational corporation, from which empirical implications are derived. In sections 3 and 4, a description of the empirical investigation approach follows as well as a presentation of the data used. Thereafter, in section 5, the implication that intrafirm sales are responsive to tax rates is tested empirically. Finally, section 6 concludes. 


\section{The Model}

The impact of transfer prices on after-tax profits can be described by a simple company model with only two locations, where the parent company is denoted by 1 and the controlled affiliate by 2 . The company's profits are determined by output

$$
f\left(k_{1}\right)+f\left(k_{2}\right),
$$

whereas $k_{1}, k_{2}$ are investments at the two locations. Opportunity costs of capital are

$$
r\left(k_{1}+k_{2}\right) .
$$

Furthermore, the company trades one product between its affiliates. Extending a model used in Haufler and Schjelderup (2000), it is considered that intrafirm sales are related to the amount of invested capital. Moreover, the company can also choose the quantity of intrafirm deliveries per invested capital. The quantity of intrafirm sales per invested capital, $k_{j}$, is denoted by $x_{j}$. Thus, the quantity $x_{1}$ per invested capital $k_{1}$ is supplied to the affiliate by the parent company 1 , and $x_{2}$ per invested capital $k_{2}$ is supplied to the parent company by the affiliate 2 , respectively.

However, optimal economic levels of intrafirm trade, denoted by $\overline{x_{j}}$, are considered by the production functions. Furthermore, as transfer prices are used as an instrument of a non-central coordination and incentive system between affiliates (e.g. Hirshleifer, 1957; Schjelderup and Sørgard, 1997; Baldenius et al., 2004), the prices of the internally delivered goods, which are optimal for decentral coordination before taxes, are assumed as $\overline{p_{j}}$. With regard to the apportionment of the company's output before taxes, these optimal coordination prices are assumed. Regularly these prices are unobservable for tax authorities

\footnotetext{
${ }^{1}$ In principle, in the case of an integrated production, calculating an economically 'true' arm's length price must fail. Nevertheless, internal price setting is used as a non-central coordination system.
} 
and are approximated by an arm's length price. However, if profits are taxed, the actual settlement prices of company-internal trading might be different and are denoted by $p_{1}, p_{2}{ }^{2}$

Apart from taxes and transaction costs, the total company profit is not affected by the amount of intrafirm sales per invested capital, $p_{j} x_{j}$. However, for tax purposes companyinternal trade has to be settled in separate accounts according to the arm's length principle. Then, the following deviation from profits before taxes can be obtained,

$$
\left(t_{2}-t_{1}\right)\left(p_{1}-\overline{p_{1}}\right) x_{1} k_{1}+\left(t_{1}-t_{2}\right)\left(p_{2}-\overline{p_{2}}\right) x_{2} k_{2}
$$

where the statutory tax rate at the location of the parent is denoted by $t_{1}$ and at the affiliate's location by $t_{2} \cdot{ }^{3}$ Obviously, a tax rate difference between both locations indicates an incentive to optimise intrafirm sales. As the price $\overline{p_{j}}$ is typically not visible to tax authorities, the settlement of the actual price $p_{j}$ constitutes a degree of freedom for multinationals. Nevertheless, it is reasonable that the probability of punishment, tax advisory costs and economic inefficiencies rise at an increasing deviation from $\overline{p_{j}}$. Especially the economic inefficiencies seem to be very important, since transfer prices and intrafirm markets are typically used as instruments of a non-central coordination and incentive system. These costs are considered by a cost function, denoted by $c_{j}\left(p_{j}\right)$. A deviation above or below the optimal coordination price before taxes, $\overline{p_{j}}$, raises these costs. Hence, the following properties are assumed

$$
c_{j}\left(\overline{p_{j}}\right)=c_{j, p}\left(\overline{p_{j}}\right)=0, \quad \operatorname{sign}\left[c_{j, p}\left(p_{j}\right)\right]=\operatorname{sign}\left[p_{j}-\overline{p_{j}}\right], \quad \frac{d^{2} c_{j}}{d p_{j}^{2}}>0
$$

Finally, a multinational company can boost a profit shift by increasing the quantity of company-internal trade per invested capital, $x_{j}$. However, a deviation from the optimal

\footnotetext{
${ }^{2}$ Prices differ from the optimal coordination price when companies use only one set of books for both tax and management purposes. An international study provided by Ernst \& Young (2001), for example, reports that 77 percent of 638 multinationals use the same transfer price for both purposes.

${ }^{3}$ Statutory tax rates are the relevant tax measures, since different determination of the tax base such as a depreciation method has no effect on shifted profits.
} 
economical level of company-internal trading per invested capital, apart from tax effects, will cause additional costs of company-internal trade, e.g. production inefficiencies or inefficiencies caused by a crowding out of open market input by intrafirm products (Grubert, 2003). Hence, the following properties of these additional costs, $e_{j}\left(x_{j}\right)$, are assumed

$$
e_{j}\left(\overline{x_{j}}\right)=e_{j, x}\left(\overline{x_{j}}\right)=0, \quad \operatorname{sign}\left[e_{j, x}\left(x_{j}\right)\right]=\operatorname{sign}\left[x_{j}-\overline{x_{j}}\right], \quad \frac{d^{2} e_{j}}{d x_{j}^{2}}>0 .
$$

Together, the following profit function can be obtained

$$
\begin{aligned}
\pi & =f\left(k_{1}\right)\left(1-t_{1}\right)+f\left(k_{2}\right)\left(1-t_{2}\right)-r\left(k_{1}+k_{2}\right) \\
& +\left[\left(t_{2}-t_{1}\right)\left(p_{1}-\overline{p_{1}}\right) x_{1}-c_{1}\left(p_{1}\right) x_{1}-e_{1}\left(x_{1}\right)\right] k_{1} \\
& +\left[\left(t_{1}-t_{2}\right)\left(p_{2}-\overline{p_{2}}\right) x_{2}-c_{2}\left(p_{2}\right) x_{2}-e_{2}\left(x_{2}\right)\right] k_{2} .
\end{aligned}
$$

Obviously, company-internal trading effects direct profit shifting from the receiving affiliate to the supplying affiliate or vice versa. ${ }^{4}$ Therefore, it can be expected that intrafirm sales, $p_{j} x_{j}$, are responsive to bilateral tax rate differences. Thus, for setting the optimum price, say by the controlled affiliate 2 , the following first-order condition can be obtained,

$$
\left(t_{1}-t_{2}\right) \stackrel{!}{=} c_{2, p}\left(p_{2}\right)
$$

Additionally, for the optimum quantity of company-internal trade of affiliate 2, we obtain

$$
\left(t_{1}-t_{2}\right)\left(p_{2}-\overline{p_{2}}\right)-c_{2}\left(p_{2}\right) \stackrel{!}{=} e_{2, x}\left(x_{2}\right)
$$

Considering the characteristics of both cost functions, the optimal price settled, $p_{2}$, increases with an increasing tax rate difference, $\left(t_{1}-t_{2}\right)$. For instance, if the tax rate difference $\left(t_{1}-t_{2}\right)$ is positive, the actual price $p_{2}$ should settle above $\overline{p_{2}}$. This effect can be extended by increasing quantities of company-internal trade in the case of a positive

\footnotetext{
${ }^{4}$ The model specification assumes an exemption system for the repatriation of foreign dividends, i.e. the tax level of the affiliate is final. This is correct considering German outbound FDI data which are used for the following empirical analysis. Germany taxes only $5 \%$ of repatriated profits.
} 
as well as a negative tax rate difference. The following comparative static analysis makes these points clearer. The comparative static properties are derived by differentiating the first-order conditions. Then, we get

$$
\begin{aligned}
d t_{1}-d t_{2} & =c_{2, p p}\left(p_{2}\right) d p_{2}, \\
\left(p_{2}-\overline{p_{2}}\right)\left(d t_{1}-d t_{2}\right)+\left[\left(t_{1}-t_{2}\right)-c_{2, p}\left(p_{2}\right)\right] d p_{2} & =e_{2, x x}\left(x_{2}\right) d x_{2} .
\end{aligned}
$$

In equation (5) the term $\left[\left(t_{1}-t_{2}\right)-c_{2, p}\left(p_{2}\right)\right]$ is zero, when the price is tax-optimally settled and condition (2) is considered. ${ }^{5}$ Then, the marginal effects of increasing tax rates on the optimal transfer price settled by affiliate 2 are

$$
\frac{d p_{2}}{d t_{2}}=-\frac{1}{c_{2, p p}\left(p_{2}\right)}=-\frac{d p_{2}}{d t_{1}} .
$$

Equation (6) shows that the optimal transfer price of deliveries to the parent 1 carried out by affiliate 2 decreases with an increasing tax rate of the affiliate 2. Equation (6) also shows the opposite effect of an increasing tax rate of the parent 1 . The optimal transfer price of the affiliate's deliveries increases with an increasing tax rate at the parent's location. Thus, the optimal transfer price increases with an increasing tax rate difference $\left(t_{1}-t_{2}\right)$.

With regard to the marginal effects of increasing tax rates on the optimal trading quantity supplied by the affiliate 2 , we obtain

$$
\frac{d x_{2}}{d t_{2}}=-\frac{p_{2}-\overline{p_{2}}}{e_{2, x x}\left(x_{2}\right)}=-\frac{d x_{2}}{d t_{1}}
$$

With regard to (7), two cases must be distinguished. First, the effect of an increasing tax rate, $t_{2}$, at the affiliate's location on $x_{2}$ is negative if $\left(p_{2}-\overline{p_{2}}\right)>0$, which requires that $\left(t_{1}-t_{2}\right)>0$. Simultaneously, the effect of an increasing tax rate, $t_{1}$, at the parent company is positive. Thus, if the tax rate difference $\left(t_{1}-t_{2}\right)$ is positive, the optimal

\footnotetext{
${ }^{5}$ However, it can be shown that the comparative static effects also hold in more general cases.
} 
quantities supplied to the parent company 1, by affiliate 2, decreases with higher tax rates at the affiliate's location, and increases with higher tax rates at the parent's location. On the other hand, if the tax rate of the parent is lower than the affiliate's tax rate, i.e. $\left(t_{1}-t_{2}\right)<0$, the effects are vice versa. This means that the quantities supplied to the parent company decrease with a higher tax rate of the parent company and increase with a higher tax rate of the affiliate. The intuition is that the optimal quantity of companyinternal trading always increases if the tax rate difference in absolute values increases.

The total effect on intrafirm sales per invested capital, $p_{j} x_{j}$, which consists of a quantity effect and a price effect, is only unambiguous if the tax rate of the receiving company is the higher rate of the two. Otherwise, the total effect might be ambiguous since the situation offers an incentive to not only underprice intrafirm trade, but also to boost quantities. Although it is reasonable that tax authorities can better control transfer prices than the choice of internally delivered quantities (Grubert, 2003), there are some good reasons for pricing dominance in practice. First, increasing quantities is then, and only then, useful if underpricing already exists. Secondly, every underpricing constitutes a basic effect on all company-internal trading, which would be carried out despite any additional intrafirm deliveries due to tax planning. These basic intrafirm deliveries are also affected by tax optimal price setting. Finally, pricing might often be easier than changing trade quantities. Particularly when intermediate goods are traded, the quantities are determined by the company's production structure and should be fairly fixed.

Overall, expecting a positive response of intrafirm sales on increasing tax rate differences seems to be reasonable. However, the expected response might be biased to a certain extent, due to increasing quantities, in cases where the tax rate of the receiving company is below the supplier's tax rate. If the opposite effect of extended quantities is dominated by the pricing effect, an increasing tax rate at the supplying affiliate's location should lead to decreasing intrafirm sales as well. Therefore, in accordance with equation (6) the 
following proposition can be empirically tested:

Proposition: If transfer prices are tax driven, intrafirm sales will decrease with an increasing statutory tax rate at the supplying affiliate's location and increase with an increasing statutory tax rate at the receiving affiliate's location.

\section{Investigation Approach}

The proposition presented above provides a testable relationship between intrafirm sales and tax rates. It can be tested empirically using firm-level financial statements of German outbound FDI. For the empirical analysis, the $M i D i$ database for multinationals, provided by the Deutsche Bundesbank, is used. This database contains financial statements of German FDI as well as additional information about the parent company.

Similar to Clausing $(2001,2006)$ and Grubert (2003), the focus is on variables reflecting intrafirm trade. The data-set used for the empirical analysis does not contain complete information on intrafirm sales of German foreign affiliates. However, due to the fact that transactions are entered in financial accounting on the delivery date and not on the payment date, the balance sheet items 'accounts receivable from affiliated companies' denoted by $A R A$ as well as 'accounts receivable from parent company' denoted by $A R P$ can be used instead. These items are available in the data-base. They reflect the shares of intrafirm sales carried out with other affiliates and the parent company, respectively, which are unpaid at the balance sheet date. ${ }^{6}$ Thus, these balance sheet items represent a snapshot of the annual internal turnover, i.e. the unpaid share of intrafirm sales at the balance sheet

\footnotetext{
${ }^{6}$ Let us consider, for example, intrafirm deliveries of intermediate goods priced at $€ 100$ to the parent company, by affiliate 2 , in November 2002, while the payment date by the parent company was in February 2003. Then, these intrafirm sales constitute 'accounts receivable from parent company' of $€ 100$ at the balance sheet date December, 31st, 2002.
} 
date. The relationship between intrafirm sales and its unpaid share at the balance sheet date depends on local costs of refinancing outstanding bills as well as on firm specifics such as a specific cash management system. A country specific lending rate constitutes a good proxy for local refinancing costs, whereas company specifics can be controlled by a company fixed effect. However, it should be emphasized that the payment date of accounts receivable is irrelevant for tax purposes, as profits or losses are entered on the delivery date and not on the payment date. ${ }^{7}$

A first set of estimations can be carried out, considering 'accounts receivable from affiliated companies', $A R A$, by means of the following equation

$$
\begin{aligned}
\ln \left(A R A_{j, k, l, t}\right) & =\alpha_{0}+\alpha_{1} S T R_{j, t}+\alpha_{2} \ln \left(C A P I T A L_{j, t}\right)+\alpha_{3} \ln \left(\text { LENDINGRATE }_{j, t}\right) \\
& +\alpha_{k}+\alpha_{l}+\alpha_{t}+\epsilon_{j, k, l, t}
\end{aligned}
$$

where $j$ denotes the affiliate, $k$ the parent and $\alpha_{t}$ a time specific effect. The statutory tax rate of the affiliate is denoted by $S T R_{j, t}$. However, the size of intrafirm sales also depends on real economic factors, since it is based on delivered goods and services. Therefore, a company effect $\alpha_{k}$ and an industry effect $\alpha_{l}$ are considered to control for unobservable heterogeneity between different company groups and industries. Moreover, in accordance with the theoretical model, the size of the affiliate's business activity is controlled for by introducing the affiliate's total invested capital, denoted by CAPITAL. However, the affiliate's total capital may be endogenous, since the analysed profit shifting opportunities may affect the size of the affiliate's business activity. For this reason, instrument variable (IV) estimations are carried out. At the first stage $\ln (\mathrm{CAPITAL})$ is regressed on all exogenous variables and the natural log of the affiliate country's GDP. Typically, GDP indicates the size of the local market. Hence, the correlation between invested capital and GDP orig-

\footnotetext{
${ }^{7} \mathrm{~A}$ company may use the implicit interest-free credit of accounts receivable for tax planning by increasing payment periods with an increasing tax rate (Bernard and Weiner, 1990). Then, the expected adverse effect of higher local taxes on 'accounts receivables from affiliated companies' due to tax-optimal transfer pricing will be underestimated to some extent.
} 
inates from sales opportunities to third parties. On the other hand, intrafirm deliveries should not be affected by the local market size, in which the affiliate is located. Thus, the natural log of GDP of the affiliate's country constitutes a suitable instrument.

In a second set of regressions, the subitem 'accounts receivable from the parent company' is considered in order to analyse transfer pricing of intrafirm sales carried out with the own parent company. Then, the specific bilateral tax rate differences are observable. Moreover, information about the bilateral distance between the affiliate's country and the parent's country, i.e. Germany, are available. Hence, the following estimation equation is used

$$
\begin{aligned}
& \ln \left(A R P_{j, k, l, t}\right)=\beta_{0}+\beta_{1}\left(S T R_{k, t}-S T R_{j, t}\right)+\beta_{2} \ln \left(C A P I T A L_{j, t}\right)+\beta_{3} \ln \left(L E N D I N G R A T E_{j, t}\right) \\
& +\beta_{4} \ln \left(D I S T A N C E_{j, k}\right)+\beta_{k}+\beta_{l}+\beta_{t}+\epsilon_{j, k, l, t} .
\end{aligned}
$$

Since $\ln (\mathrm{CAPITAL})$ may be endogenous, IV estimations are carried out, where $\ln (\mathrm{GDP})$ is used as an instrument variable. With regard to the tax effects, a negative sign of $\alpha_{1}$ and a positive sign of $\beta_{1}$ is expected according to our proposition.

\section{Data and Descriptive Statistics}

The empirical analysis uses the MiDi database for multinationals provided by the Deutsche Bundesbank. This is a comprehensive annual micro database of direct investment positions of German enterprises held abroad as well as direct investment positions held in Germany by foreign companies. However, this analysis is based only on data of German outbound FDI positions. The data provides annual information about the balance sheet of each investment object, including further information on the type of investment and on the investor. ${ }^{8}$ A favourable characteristic of the data set is the opportunity to trace direct

\footnotetext{
${ }^{8}$ See Lipponer (2006) for a detailed description of the data set.
} 
Table 1: German controlled outbound FDI 1996 - 2003

\begin{tabular}{|c|c|c|c|c|c|c|}
\hline Destination & Number & $\begin{array}{l}\text { CAPITAL } \\
\text { (Mean, } \\
\in 1,000)\end{array}$ & $\begin{array}{c}\text { Accounts } \\
\text { Receivable } \\
\text { from Affiliates } \\
(\text { Mean, } € 1,000)\end{array}$ & Number & $\begin{array}{l}\text { CAPITAL } \\
\text { (Mean, } \\
€ 1,000)\end{array}$ & $\begin{array}{c}\text { Accounts } \\
\text { Receivable } \\
\text { from Parent } \\
(\text { Mean, } € 1,000)\end{array}$ \\
\hline Australia & 587 & 22,443 & 3,228 & 233 & 28,759 & 1,411 \\
\hline Austria & 1,996 & 37,178 & 8,674 & 716 & 43,327 & 4,487 \\
\hline Belgium & 1,198 & 59,721 & 13,280 & 487 & 40,154 & 3,447 \\
\hline Canada & 411 & 44,640 & 4,370 & 130 & 70,763 & 1,690 \\
\hline Czech Republic & 1,320 & 35,467 & 2,123 & 554 & 47,625 & 1,303 \\
\hline Denmark & 575 & 24,525 & 2,274 & 237 & 28,889 & 1,581 \\
\hline Estonia & -* & & - & -* & & - \\
\hline Finland & 212 & 22,488 & 4,044 & 92 & 28,088 & 3,122 \\
\hline France & 3,125 & 37,156 & 5,462 & 1,434 & 37,466 & 3,068 \\
\hline Great Britain & 2,057 & 39,893 & 6,399 & 902 & 36,155 & 2,615 \\
\hline Greece & 233 & 34,062 & 1,805 & 124 & 31,596 & 1,010 \\
\hline Hungary & 878 & 45,186 & 7,093 & 319 & 58,018 & 10,598 \\
\hline Ireland & 257 & 23,300 & 5,197 & 101 & 24,098 & 2,480 \\
\hline Italy & 2,266 & 41,000 & 4,103 & 960 & 43,350 & 2,081 \\
\hline Japan & 657 & 67,921 & 6,893 & 332 & 92,900 & 3,210 \\
\hline Latvia & 23 & 11,623 & 477 & 12 & 15,625 & 528 \\
\hline Lithuania & 28 & 8,229 & 2,358 & $-^{*}$ & - & - \\
\hline Luxembourg & 40 & 25,282 & 4,072 & 16 & 31,716 & 3,236 \\
\hline Malta & -* & & - & -* & & - \\
\hline Mexico & 397 & 98,198 & 10,612 & 141 & 51,462 & 1,718 \\
\hline Netherlands & 1,482 & 40,071 & 13,811 & 554 & 32,339 & 3,744 \\
\hline New Zealand & 97 & 10,324 & 675 & 44 & 12,593 & 1,041 \\
\hline Norway & 229 & 37,522 & 4,328 & 92 & 40,749 & 4,536 \\
\hline Poland & 1,261 & 24,549 & 1,863 & 400 & 29,390 & 1,296 \\
\hline Portugal & 237 & 32,312 & 6,712 & 117 & 45,703 & 6,234 \\
\hline Slovakia & 290 & 31,968 & 2,075 & 94 & 44,237 & 3,607 \\
\hline Slovenia & 129 & 18,306 & 3,169 & 61 & 15,798 & 1,626 \\
\hline Spain & 1,966 & 43,902 & 5,398 & 794 & 41,308 & 2,346 \\
\hline Sweden & 715 & 27,378 & 5,408 & 282 & 32,179 & 2,162 \\
\hline Switzerland & 1,990 & 24,032 & 4,796 & 901 & 25,310 & 2,938 \\
\hline USA & 2,117 & 96,135 & 13,611 & 851 & 84,208 & 3,512 \\
\hline Total & 26,786 & 42,908 & 6,635 & 10,991 & 43,198 & 3,009 \\
\hline
\end{tabular}


investment positions of individual firms over time. The panel data structure and the ability to identify all foreign affiliates belonging to a specific multinational company make it possible to control for heterogeneity across companies. The collection of the data is enforced by German law, which determines reporting mandates for certain international transactions and positions. ${ }^{9}$ The version used provides firm-level panel data for the period of 1996 to 2003. Since the model deals with an enterprise optimising intrafirm sales between each affiliate, only observations displaying a participation level above 50 per cent are taken into account. The reported figures are based on a sample of firm observations which display positive real capital and turnover for every reported year. Furthermore, due to the fact that the underlying model deals with a simple two-tier company structure of a firm which actually produces at home and abroad, indirectly held investments as well as holdings and financial service providers are excluded. ${ }^{10}$ Table 1 presents the spatial apportionment of the considered German FDI from 1996 until 2003.

According to equations (8) and (9), the natural log of firm-level 'accounts receivable from affiliates' as well as 'accounts receivable from the parent company' are kept as dependent variables. Moreover, total capital (CAPITAL) and total turnover (TURNOVER) of each affiliate are taken from the $M i D i$ database. As unpaid dividends and interest of financial assets may cause higher accounts receivable, a dummy variable DFIN is used. This DFIN represents financial interests in affiliated companies, having the value one, while otherwise zero. It is reasonable to assume that the opportunity to plan tax-optimal intrafirm sales is higher if an affiliate is wholly owned compared to quoted share holdings (Kant, 1990). Therefore, a dummy variable DWO is used, which has the value one if the affiliate is wholly

\footnotetext{
${ }^{9}$ Sec. 26 Aussenwirtschaftsgesetz (Law on Foreign Trade and Payments) in connection with Aussenwirtschaftsverordnung (Foreign Trade and Payment Regulations). Each German multinational has to report its foreign assets including both direct FDI and indirect FDI conditional on some lower threshold level for mandatory reporting. Since 2002, FDI has to be reported, if the participation is $10 \%$ or more and the balance sheet total of the foreign object is above 3 million Euro. Though previous years showed lower threshold levels, this threshold level is uniformly applied for all years in the panel.

${ }^{10}$ Surprisingly at first sight, a neighbouring country like Luxembourg captures only a small share of German FDI observations. Given the fact that companies are excluded which likely do not produce goods, i.e. holdings or financial service providers, this is very reasonable.
} 
Table 2: Descriptive Statistics

\begin{tabular}{|c|c|c|c|c|c|}
\hline Variable & Definition & Mean & Std.Dev. & Min. & Max. \\
\hline ARA & $\begin{array}{l}\text { Firm level variables } \\
\text { accounts receivable from } \\
\text { affiliates in } € \text { thousand }\end{array}$ & 6,635 & 80,970 & 1 & $6,289,124$ \\
\hline $\operatorname{ARP}^{a)}$ & $\begin{array}{l}\text { accounts receivable from parent } \\
\text { company in } € \text { thousand }\end{array}$ & 3,009 & 19,144 & 1 & $1,016,158$ \\
\hline CAPITAL & total assets in $€$ thousand & 42,908 & 298,621 & 3,000 & $35,600,000$ \\
\hline TURNOVER & turnover in $€$ thousand & 67,014 & 450,047 & 1,000 & $51,900,000$ \\
\hline DFIN & binary & .283 & .451 & 0 & 1 \\
\hline DLCF & binary & .276 & .447 & 0 & 1 \\
\hline DWO & binary & .831 & .375 & 0 & 1 \\
\hline \multicolumn{6}{|c|}{ Tax variables } \\
\hline $\operatorname{STR}_{G E}^{a)}$ & German stat. tax rate & .418 & .020 & .392 & .439 \\
\hline $\operatorname{STR}_{F}$ & foreign stat. tax rate & .346 & .070 & .0 & .532 \\
\hline $\operatorname{STR}_{G E-\mathrm{STR}_{F}}^{a)}$ & tax rate difference & .072 & .069 & -.094 & .435 \\
\hline \multicolumn{6}{|c|}{ Further characteristics } \\
\hline LENDING RATE & local lending rate & .073 & .042 & .018 & .364 \\
\hline $\operatorname{DISTANCE}^{a)}$ & flight distance in $\mathrm{km}$ & 1,978 & 3,294 & 190 & 18,162 \\
\hline GDP & in billion US dollars & 1,424 & 2,438 & 7.2 & 10,600 \\
\hline
\end{tabular}

26,786 observations. ${ }^{a)}: 10,991$ observation.

owned, and zero if not.

The variable $S T R_{G E}$ contains German statutory profit tax rates. ${ }^{11}$ Foreign statutory tax rates are kept by the variable $S T R_{F}$. While using these two statutory tax rates, bilateral tax rate differences are constructed. The statutory tax rate is the relevant tax measure if an affiliate does not exhibit any loss carry forward or any current losses. For this reason the dummy variable DLCF is used as an indicator for the possibility to offset former losses with actual profits for tax purposes taking on the value one, while otherwise zero.

\footnotetext{
${ }^{11} \mathrm{An}$ average level of the local German trade income tax (Gewerbesteuer) is considered.
} 
The country specific lending rate (LENDING RATE) is used as an appropriate proxy of refinancing costs in order to control impacts of different payment policies. Additionally, a variable DISTANCE is used, containing the average flight distance between Germany and the affiliate's country. Finally, the affiliate's country GDP is used. Table 2 presents descriptive statistics of the data used for the samples. Included are 26,786 German outbound observations exhibiting 'accounts receivable from affiliated companies' and 10,991 observations exhibiting 'accounts receivable from parent company', which are located in 31 countries during the period from 1996 until 2003.

\section{$5 \quad$ Regression Results}

The tax impact on intrafirm sales is analysed using German outbound FDI data. Empirical analysis is based on the estimation equations (8) and (9). First, the natural log of 'accounts receivable from affiliated companies' is used as a dependent variable. Further analyses are focused on the subitem 'accounts receivable from parent company' in order to provide additional insights.

A first set of results is presented in table 3, where the natural log of 'accounts receivable from affiliated companies' is used as the dependent variable. According to the theoretical model, all specifications presented in table 3 indicate a significant negative impact of a higher tax rate at the affiliate's location on 'accounts receivable from affiliates'. This result can be interpreted as a negative impact of a higher tax rate on intrafirm sales since the item 'accounts receivable from affiliates' constitutes a snapshot of annual intrafirm sales.

Since different local lending rates reflect different incentives to pay internal bills, a negative effect of a higher local lending rate on unpaid accounts receivable, at the balance sheet 
Table 3: Transfer Pricing of Intrafirm Sales

\begin{tabular}{|c|c|c|c|c|c|}
\hline Dependent Variable & \multicolumn{5}{|c|}{ Natural log of accounts receivable from affiliates } \\
\hline $\mathrm{STR}_{F}$ & $\begin{array}{c}-1.45^{* *} \\
(.513)\end{array}$ & $\begin{array}{c}-2.14^{* *} \\
(.487)\end{array}$ & $\begin{array}{c}-2.02^{* *} \\
(.543)\end{array}$ & $\begin{array}{c}-2.41^{* *} \\
(.709)\end{array}$ & $\begin{array}{c}-3.38^{* *} \\
(.693)\end{array}$ \\
\hline $\ln (\mathrm{CAPITAL})$ & $\begin{array}{l}.509^{* *} \\
(.124)\end{array}$ & $\begin{array}{l}.489^{* *} \\
(.117)\end{array}$ & $\begin{array}{l}.549^{* *} \\
(.117)\end{array}$ & $\begin{array}{l}.501^{* *} \\
(.122)\end{array}$ & $\begin{array}{l}.512^{* *} \\
(.110)\end{array}$ \\
\hline $\ln ($ LENDING RATE) & $\begin{array}{r}-.669^{* *} \\
(.089)\end{array}$ & $\begin{array}{c}-.606^{* *} \\
(.078)\end{array}$ & $\begin{array}{r}-.637^{* *} \\
(.086)\end{array}$ & $\begin{array}{r}-.674^{* *} \\
(.089)\end{array}$ & $\begin{array}{r}-.583^{* *} \\
(.076)\end{array}$ \\
\hline $\mathrm{STR}_{F} \mathrm{xDFIN}$ & & $\begin{array}{l}1.93^{* *} \\
(.464)\end{array}$ & & & $\begin{array}{l}2.05^{* *} \\
(.475)\end{array}$ \\
\hline DFIN & & $\begin{array}{c}.241 \\
(.167)\end{array}$ & & & $\begin{array}{c}.177 \\
(.171)\end{array}$ \\
\hline $\mathrm{STR}_{F} \mathrm{xDLCF}$ & & & $\begin{array}{l}2.10^{* *} \\
(.507)\end{array}$ & & $\begin{array}{l}2.17^{* *} \\
(.494)\end{array}$ \\
\hline DLCF & & & $\begin{array}{r}-.957^{* *} \\
(.176)\end{array}$ & & $\begin{array}{c}-.948^{* *} \\
(.171)\end{array}$ \\
\hline $\mathrm{STR}_{F} \mathrm{xDWO}$ & & & & $\begin{array}{l}1.21^{*} \\
(.592)\end{array}$ & $\begin{array}{c}.846 \\
(.561)\end{array}$ \\
\hline DWO & & & & $\begin{array}{c}-.348 \\
(.224)\end{array}$ & $\begin{array}{l}-.184 \\
(.213)\end{array}$ \\
\hline $\mathrm{R}^{2}$ & .095 & .144 & .099 & .095 & .148 \\
\hline
\end{tabular}

All regressions are IV estimations. At the first stage $\ln (\mathrm{CAPITAL})$ is regressed on all exogenous variables and $\ln (\mathrm{GDP})$. Only second stage regression results are presented. F-tests of the significance of the first stage specifications are all significant at 1\% level. Standard errors are in parentheses, which are clustered within 224 year-country cells and robust against random firmspecific and country effects using the Huber-White sandwich formula. A star denotes significance at the $5 \%$ level and two stars at the $1 \%$ level. All estimates include a full set of 2,565 firm, 46 industry and time fixed effects. There are 26,786 observations.

date, confirms the theoretical expectations. The higher local costs of refinancing are, the faster accounts receivable are paid by an affiliated company. However, since intrafirm sales are based on delivered goods and services, the amount of internal turnover depends on real economic issues. For this reason, unobservable heterogeneity of the company group is controlled for by firm and industry fixed effects. Finally, in accordance with our assumption that the size of intrafirm sales is related to the size of invested capital, the natural log of 
invested capital is considered. It is confirmed that business activity exhibiting higher total capital is associated with higher intrafirm sales.

The specifications (2)-(5) of table 3 provide deeper insights into the tax effects on intrafirm sales. First, companies that hold shares of affiliates or give loans to them might have higher 'accounts receivable from affiliates' at the balance sheet date, resulting from unpaid dividends or interest. Therefore, the regressions presented in columns (2) and (5) of table 3 are carried out, including a dummy variable DFIN as well as an interaction of this dummy with the tax rate difference. Affiliates, which have financial interests in affiliated companies such as shareholding or giving credit, exhibit less tax sensitivity of their 'accounts receivable from affiliates'. ${ }^{12}$ Secondly, a dummy DLCF is introduced that indicates if affiliates carry forward losses. Then the effective tax burden of marginal additional profit amounts to zero, i.e. these cases shape a suitable control group. This expectation is confirmed by specifications (3) and (5), which indicate significantly less tax sensitivity of 'accounts receivable from affiliates' in cases where an affiliate exhibits a loss carryforward. These results are in line with MacKie-Mason (1990), who finds significantly less tax planning sensitivity of US firms by means of financing in the case of companies suffering losses. Thirdly, a dummy variable DWO is introduced indicating affiliates that are wholly owned by a German parent company. With additional minority shareholders, tax planning, by means of company-internal profit shifting, is limited by a conflict of interest with outside shareholders. Thus, it might be reasonable to assume that profit shifting works better, if an affiliate is wholly owned by one parent company. Moreover, in accordance with Kant (1990) it can be expected that affiliates, which are not wholly-owned, exhibit higher intrafirm sales, since dominant shareholders have an incentive to shift profits into its wholly-owned affiliates. However, both expectations cannot be confirmed by our regressions considering 'accounts receivable from affiliates'.

\footnotetext{
${ }^{12}$ In particular, inter-corporate dividends are often tax exempt.
} 
The semi-elasticities indicated by the tax coefficients is interpreted as follows: Specification (5), presented in table 3 , indicates a 3.38 per cent smaller 'accounts receivable from affiliated companies' in the case of affiliates without a loss carryforward and financial interests in affiliated companies, if the tax rate is increased by one percentage point. In the case of affiliates that exhibit a loss carryforward, the total effect of one percentage point higher tax rates on 'accounts receivable from affiliates' comes down to 1.2 per cent. An additional set of results presented in table 5 in the appendix shows that the results are also very robust if the affiliate's total turnover is used as an alternative measure for the size of the business activity.

Furthermore, the tax impact on intrafirm sales can be analysed considering only 'accounts receivable from German parent company' as the dependent variable. In contrast to the former set of analyses, a bilateral tax rate difference can be considered. The IV regression results presented in table 4 are based on equation (9). According to the theoretical model, the basic specification presented in column (1) of table 4 indicates a significantly positive impact of a higher tax rate difference between Germany and the affiliate's location on 'accounts receivable from parent company'. Since accounts receivable due from intrafirm deliveries constitute a snapshot of the annual intrafirm sales, this result also indicates a significant impact of the tax rate difference on intrafirm sales.

Considering the control variables used in these regressions, the results match theoretical expectations. The negative effect of a higher local lending rate on unpaid accounts receivable, at the balance sheet date, confirms the theoretical expectations of payment policy. Business activities exhibiting higher total capital are associated with higher intrafirm sales. Additionally, since only one bilateral supply chain is considered, the distance of deliveries is observable. Therefore, the flight distance between Germany and the affiliate's location is introduced in order to control for an additional aspect determining intrafirm deliveries of goods and services. Theoretical expectations are confirmed by a significantly negative 
effect of a higher distance on affiliate's 'accounts receivable from parent company'.

Table 4: Transfer Pricing of Intrafirm Sales with Parent Company

\begin{tabular}{|c|c|c|c|c|c|}
\hline Dependent Variable & \multicolumn{5}{|c|}{ Natural log of accounts receivable from German parent } \\
\hline $\mathrm{STR}_{G E^{-}} \mathrm{STR}_{F}$ & $\begin{array}{l}1.70^{* *} \\
(.614)\end{array}$ & $\begin{array}{l}1.56^{* *} \\
(.590)\end{array}$ & $\begin{array}{l}2.41^{* *} \\
(.657)\end{array}$ & $\begin{array}{l}-.373 \\
(1.13)\end{array}$ & $\begin{array}{l}.121 \\
(1.07)\end{array}$ \\
\hline $\ln (\mathrm{CAPITAL})$ & $\begin{array}{l}.844^{* *} \\
(.137)\end{array}$ & $\begin{array}{l}.844^{* *} \\
(.145)\end{array}$ & $\begin{array}{l}.873^{* *} \\
(.131)\end{array}$ & $\begin{array}{l}.832^{* *} \\
(.136)\end{array}$ & $\begin{array}{l}.863^{* *} \\
(.139)\end{array}$ \\
\hline ln(LENDING RATE) & $\begin{array}{r}-.410^{* *} \\
(.088)\end{array}$ & $\begin{array}{c}-.408^{* *} \\
(.085)\end{array}$ & $\begin{array}{c}-.380^{* *} \\
(.085)\end{array}$ & $\begin{array}{r}-.400^{* *} \\
(.088)\end{array}$ & $\begin{array}{c}-.368^{* *} \\
(.082)\end{array}$ \\
\hline $\ln (\mathrm{DISTANCE})$ & $\begin{array}{c}-.219^{* *} \\
(.029)\end{array}$ & $\begin{array}{c}-.219^{* *} \\
(.030)\end{array}$ & $\begin{array}{c}-.214^{* *} \\
(.028)\end{array}$ & $\begin{array}{r}-.218^{* *} \\
(.029)\end{array}$ & $\begin{array}{c}-.213^{* *} \\
(.029)\end{array}$ \\
\hline$\left(\mathrm{STR}_{G E}-\mathrm{STR}_{F}\right) \mathrm{xDFIN}$ & & $\begin{array}{l}.503 \\
(.771)\end{array}$ & & & $\begin{array}{l}.351 \\
(.761)\end{array}$ \\
\hline DFIN & & $\begin{array}{l}-.023 \\
(.127)\end{array}$ & & & $\begin{array}{l}-.038 \\
(.123)\end{array}$ \\
\hline$\left(\mathrm{STR}_{\left.G E^{-}-\mathrm{STR}_{F}\right) \mathrm{xDLCF}}\right.$ & & & $\begin{array}{l}-2.73^{* *} \\
(.705)\end{array}$ & & $\begin{array}{l}-2.76^{* *} \\
(.725)\end{array}$ \\
\hline DLCF & & & $\begin{array}{l}.014 \\
(.077)\end{array}$ & & $\begin{array}{l}-.019 \\
(.077)\end{array}$ \\
\hline$\left(\mathrm{STR}_{G E^{-}} \mathrm{STR}_{F}\right) \mathrm{xDWO}$ & & & & $\begin{array}{l}2.24^{*} \\
(1.11)\end{array}$ & $\begin{array}{l}2.37^{*} \\
(1.09)\end{array}$ \\
\hline DWO & & & & $\begin{array}{c}.034 \\
(.103)\end{array}$ & $\begin{array}{l}.035 \\
(.102)\end{array}$ \\
\hline $\mathrm{R}^{2}$ & .081 & .090 & .087. & .082 & .095 \\
\hline
\end{tabular}

All regressions are IV estimations. At the first stage $\ln ($ CAPITAL) is regressed on all exogenous variables and $\ln (\mathrm{GDP})$. Only second stage regression results are presented. F-tests of the significance of the first stage specifications are all significant at $1 \%$ level. Standard errors are in parentheses, which are clustered within 222 year-country cells and robust against random firmspecific and country effects using the Huber-White sandwich formula. A star denotes significance at the $5 \%$ level and two stars at the $1 \%$ level. All estimates include a full set of 1,383 firm, 46 industry and time fixed effects. There are 10,991 observations.

Similar to the first set of results presented in table 3, additional specifications (2)-(5) are presented in table 4, which can provide deeper insights into tax effects on intrafirm sales carried out with the parent company. The dummy variables, which indicate financial interests in affiliated companies, a loss carryforward, as well as complete ownership by a 
German parent, are the same as used in the former set of regressions presented in table 3. In contrast to the former results, a different tax sensitivity with respect to 'accounts receivable from parent company' cannot be confirmed by columns (2) and (5) in cases in which affiliates have financial interests in affiliated companies. This suggests that in practice having financial interests within the parent company might be less relevant compared to financial interests in other affiliated companies. With regard to exhibiting a loss carryforward, the estimations in columns (3) and (5) of table 4 confirm that an affiliate, which can offset actual profits with former losses, has an opposite tax incentive to manipulate intrafirm sales. Furthermore, the results in columns (4) and (5) confirm that profit shifting works better if an affiliate is wholly owned by one parent. The positive impact of the interaction between the tax rate difference and the dummy indicating wholly-owned affiliates is significant, whereas the tax effect considering all affiliates becomes insignificant. This result is in line with Desai, Foley and Hines (2004), who find that wholly-owned affiliates are more responsive to tax planning incentives.

The semi-elasticity indicated by the tax rate difference can be interpreted as follows: Specification (5) presented in table 4 indicates a 2.37 per cent higher 'accounts receivable from parent company' of wholly owned affiliates without exhibiting any loss carryforward, if the tax rate difference is increased by one percentage point. The results are very robust considering alternative specifications presented in table 6 in the appendix. In comparison to the semi-elasticities, estimated using the item 'accounts receivable from affiliated companies', the tax response is also very similar. Moreover, in comparison to results of previous studies based on US data, the magnitudes of our estimated tax response are quite similar. For example, Clausing (2006) reports a tax response of the intrafirm trade balance of approximately - 1.3 with regard to an one percentage point higher tax rate. A similar specification, presented in column (1) of table 3, indicates a similar tax semi-elasticity of intrafirm sales of about - 1.45. However, a higher semi-elasticity of about - 3.38 is estimated when considering only affiliates without a loss carryforward. 


\section{Conclusion}

By using the presented investigational approach, which focuses directly on balance sheet items reflecting intrafirm sales, it can be confirmed that transfer pricing of intrafirm sales represents a relevant channel to shift profits. The regression results clearly confirm the expected impact of the tax rate on the size of 'accounts receivable from affiliated companies', as well as on 'accounts receivable from parent company', and thus on intrafirm sales. When interpreting the empirical results, it should be emphasized that it is not possible to identify the magnitude of the transfer pricing effect against the quantity effect. However, the estimated response of 'accounts receivable from affiliated companies' indicates that tax optimal transfer pricing is possible. That means shifting works effectively despite anti-avoidance legislations and tax audits based on the arm's length principle. Thus, the results suggest that multinationals can evade taxation in high tax countries for the benefit of locations offering lower tax rates.

Cosidering for example column (5) in table 3, the estimated total semi-elasticity of intrafirm sales with regard to a smaller tax rate at the supplying affiliate is - 3.38. This suggests that the transfer price response with regard to an one percentage point smaller tax rate might be more than one. Thus, reducing statutory tax rate differences seems to remain a promising strategy for countries trying to attract tax bases. Nevertheless, be aware that these can only be rough estimates, since it is impossible to identify the magnitude of the transfer pricing effect against the quantity effect, which in turn does not constitute a direct effect on taxable profits. Only the response of the transfer price with regard to the tax rate constitutes directly an equal effect on reported taxable profits at the respective affiliate. However, the results are quite similar in comparison to results of previous studies based on US data.

For companies, the tax impact on transfer prices is related with distortions due to ineffi- 
ciencies from misleading decentralized coordination. Furthermore, from a theoretical point of view, the evidence on cross-country profit shifting activities suggests that multinationals have enhanced opportunities compared to purely national firms. Nevertheless, further empirical research seems to be useful to analyse the effects of profit shifting opportunities on companies' investment decisions. Finally, the provided evidence on transfer pricing of intrafirm sales as one relevant channel of profit shifting might be useful for further research considering the European tax competition process.

\section{Datasources and Definitions}

Firm-level data are taken from the MiDi dataset of the Bundesbank, see Lipponer (2006) for an overview.

Distance is taken from "http://www.etn.nl/distance.htm". It contains flight distance in $\mathrm{km}$.

GDP in US dollars, nominal, taken from OECD Economic Outlook (2005) 77.

Lending Rate is the lending rate for loans to the private sector, taken from the IMF International Financial Yearbook (2005), augmented with corresponding ECB figures, that are taken from "http://www.ecb.int/stats/pdf/money/interest/rir_nnrir.pdf".

Statutory tax rates are taken from the IBFD databases and from tax surveys provided by the tax advisory companies Ernst\&Young, PwC and KPMG. 


\section{Appendix}

\section{Alternative Specifications}

Table 5: Transfer Pricing of Intrafirm Sales

\begin{tabular}{|c|c|c|c|c|c|}
\hline Dependent Variable & \multicolumn{5}{|c|}{ Natural log of accounts receivable from affiliates } \\
\hline $\mathrm{STR}_{F}$ & $\begin{array}{c}-1.31^{* *} \\
(.490)\end{array}$ & $\begin{array}{c}-2.01^{* *} \\
(.470)\end{array}$ & $\begin{array}{c}-1.86^{* *} \\
(.521)\end{array}$ & $\begin{array}{c}-2.21^{* *} \\
(.691)\end{array}$ & $\begin{array}{c}-3.16^{* *} \\
(.678)\end{array}$ \\
\hline $\ln ($ TURNOVER) & $\begin{array}{l}.514^{* *} \\
(.125)\end{array}$ & $\begin{array}{l}.492^{* *} \\
(.118)\end{array}$ & $\begin{array}{l}.549^{* *} \\
(.117)\end{array}$ & $\begin{array}{l}.507^{* *} \\
(.124)\end{array}$ & $\begin{array}{l}.511^{* *} \\
(.110)\end{array}$ \\
\hline $\ln (\mathrm{LENDING} \mathrm{RATE})$ & $\begin{array}{c}-.657^{* *} \\
(.090)\end{array}$ & $\begin{array}{c}-.592^{* *} \\
(.080)\end{array}$ & $\begin{array}{c}-.628^{* *} \\
(.087)\end{array}$ & $\begin{array}{c}-.662^{* *} \\
(.090)\end{array}$ & $\begin{array}{c}-.571^{* *} \\
(.077)\end{array}$ \\
\hline $\mathrm{STR}_{F} \mathrm{xDFIN}$ & & $\begin{array}{l}1.93^{* *} \\
(.464)\end{array}$ & & & $\begin{array}{l}2.05^{* *} \\
(.475)\end{array}$ \\
\hline DFIN & & $\begin{array}{c}.286 \\
(.165)\end{array}$ & & & $\begin{array}{c}.228 \\
(.168)\end{array}$ \\
\hline $\mathrm{STR}_{F} \mathrm{xDLCF}$ & & & $\begin{array}{l}2.08^{* *} \\
(.506)\end{array}$ & & $\begin{array}{l}2.16^{* *} \\
(.494)\end{array}$ \\
\hline DLCF & & & $\begin{array}{c}-.924^{* *} \\
(.175)\end{array}$ & & $\begin{array}{c}-.916^{* *} \\
(.171)\end{array}$ \\
\hline $\mathrm{STR}_{F} \mathrm{xDWO}$ & & & & $\begin{array}{c}1.12 \\
(.595)\end{array}$ & $\begin{array}{c}.746 \\
(.564)\end{array}$ \\
\hline DWO & & & & $\begin{array}{l}-.329 \\
(.225)\end{array}$ & $\begin{array}{l}-.161 \\
(.214)\end{array}$ \\
\hline $\mathrm{R}^{2}$ & .095 & .144 & .099 & .095 & .148 \\
\hline
\end{tabular}

All regressions are IV estimations. At the first stage $\ln$ (TURNOVER) is regressed on all exogenous variables and $\ln (\mathrm{GDP})$. Only second stage regression results are presented. F-tests of the significance of the first stage specifications are all significant at 1\% level. Standard errors are in parentheses, which are clustered within 224 year-country cells and robust against random firmspecific and country effects using the Huber-White sandwich formula. A star denotes significance at the $5 \%$ level and two stars at the $1 \%$ level. All estimates include a full set of 2,565 firm, 46 industry and time fixed effects. There are 26,786 observations. 
Table 6: Transfer Pricing of Intrafirm Sales with Parent Company

\begin{tabular}{|c|c|c|c|c|c|}
\hline \multirow{2}{*}{$\begin{array}{l}\text { Dependent Variable } \\
\operatorname{STR}_{G E}-\mathrm{STR}_{F}\end{array}$} & \multicolumn{5}{|c|}{$\begin{array}{l}\text { Natural log of accounts receivable from German parent } \\
\begin{array}{lll}(1) & (2)\end{array}\end{array}$} \\
\hline & $\begin{array}{l}1.50^{*} \\
(.593)\end{array}$ & $\begin{array}{l}1.37^{* *} \\
(.572)\end{array}$ & $\begin{array}{l}2.22^{* *} \\
(.639)\end{array}$ & $\begin{array}{l}-.854 \\
(1.11)\end{array}$ & $\begin{array}{l}-.385 \\
(1.05)\end{array}$ \\
\hline ln(TURNOVER) & $\begin{array}{l}.831^{* *} \\
(.135)\end{array}$ & $\begin{array}{l}.820^{* *} \\
(.141)\end{array}$ & $\begin{array}{l}.856^{* *} \\
(.129)\end{array}$ & $\begin{array}{l}.820^{* *} \\
(.134)\end{array}$ & $\begin{array}{l}.836^{* *} \\
(.135)\end{array}$ \\
\hline $\ln$ (LENDING RATE) & $\begin{aligned}-.422^{* *} \\
(.087)\end{aligned}$ & $\begin{array}{c}-.415^{* *} \\
(.084)\end{array}$ & $\begin{aligned}-.395^{* *} \\
(.084)\end{aligned}$ & $\begin{array}{r}-.409^{* *} \\
(.087)\end{array}$ & $\begin{array}{c}-.375^{* *} \\
(.082)\end{array}$ \\
\hline $\ln ($ DISTANCE) & $\begin{array}{r}-.194^{* *} \\
(.029)\end{array}$ & $\begin{aligned}-.191^{* *} \\
(.029)\end{aligned}$ & $\begin{aligned}-.189^{* *} \\
(.028)\end{aligned}$ & $\begin{aligned}-.193^{* *} \\
(.028)\end{aligned}$ & $\begin{aligned}-.185^{* *} \\
(.028)\end{aligned}$ \\
\hline$\left(\mathrm{STR}_{G E-} \mathrm{STR}_{F}\right) \mathrm{xDFIN}$ & & $\begin{array}{l}.574 \\
(.774)\end{array}$ & & & $\begin{array}{l}.425 \\
(.764)\end{array}$ \\
\hline DFIN & & $\begin{array}{l}.057 \\
(.116)\end{array}$ & & & $\begin{array}{l}.049 \\
(.112)\end{array}$ \\
\hline$\left(\mathrm{STR}_{G E^{-}} \mathrm{STR}_{F}\right) \mathrm{xDLCF}$ & & & $\begin{array}{l}-2.81^{* *} \\
(.707)\end{array}$ & & $\begin{array}{l}-2.83^{* *} \\
(.726)\end{array}$ \\
\hline DLCF & & & $\begin{array}{l}.022 \\
(.071)\end{array}$ & & $\begin{array}{l}-.023 \\
(.079)\end{array}$ \\
\hline$\left(\mathrm{STR}_{G E^{-}} \mathrm{STR}_{F}\right) \mathrm{xDWO}$ & & & & $\begin{array}{l}2.60^{*} \\
(1.12)\end{array}$ & $\begin{array}{l}2.77^{*} \\
(1.10)\end{array}$ \\
\hline DWO & & & & $\begin{array}{l}-.009 \\
(.103)\end{array}$ & $\begin{array}{l}-.014 \\
(.102)\end{array}$ \\
\hline $\mathrm{R}^{2}$ & .081 & .090 & .087 & .082 & .095 \\
\hline
\end{tabular}

All regressions are IV estimations. At the first stage $\ln$ (TURNOVER) is regressed on all exogenous variables and $\ln (\mathrm{GDP})$. Only second stage regression results are presented. F-tests of the significance of the first stage specifications are all significant at $1 \%$ level. Standard errors are in parentheses, which are clustered within 222 year-country cells and robust against random firmspecific and country effects using the Huber-White sandwich formula. A star denotes significance at the $5 \%$ level and two stars at the $1 \%$ level. All estimates include a full set of 1,383 firm, 46 industry and time fixed effects. There are 10,991 observations. 


\section{References}

Baldenius, T., N.D. Melumad and S. Reichelstein (2004), Integrating managerial and tax objectives in transfer pricing, Accounting Review 79, 591-615.

Bernard, J.T. and R.J. Weiner (1990), Multinational corporations, transfer prices, and taxes: Evidence from the U.S. petroleum industry, in: Taxation in the global economy, edited by A. Razin and J. Slemrod, London, 123-159.

Clausing, K.A. (2001), The impact of transfer pricing on intrafirm trade, in: International taxation and multinational activity, edited by J.R. Hines, Chicago, 173-194.

Clausing, K.A. (2003), Tax-motivated transfer pricing and US intrafirm trade prices, Journal of Public Economics 87, 2207-2223.

Clausing, K.A. (2006), International tax avoidance and U.S. international trade, National Tax Journal 59, 269-287.

Desai, M.A., C.F. Foley and J.R. Hines (2004), The costs of shared ownership: Evidence from international joint ventures, Journal of Financial Economics 73, 323-374.

Devereux, M. (2006), The impact of taxation on the location of capital, firms and profit: A survey of empirical evidence, Working paper, University of Warwick.

Ernst \& Young (2001), Transfer Pricing 2001 Global Survey, http:/ /www.ey.com/global/ download.nsf/Germany/Transfer_Pricing_2002/file/Tranfer_Pricing_2002.pdf.

Grubert, H. and J. Mutti (1991), Taxes, tariffs and transfer pricing in multinational corporate decision making, Review of Economics and Statistics 73, 285-293.

Grubert, H. (2003), Intangible income, intercompany transactions, income shifting, and the choice of location, National Tax Journal 56, 221-242.

Haufler, A. and G. Schjelderup (2000), Corporate tax systems and cross country profit shifting, Oxford Economic Papers 52, 306-325. 
Hines, J.R. and E.M. Rice (1994), Fiscal paradise: Foreign tax havens and American business, Quarterly Journal of Economics 109, 149-182.

Hines, J.R. (1999), Lessons from behavioral responses to international taxation, National Tax Journal 52, 305-322.

Hirshleifer, J. (1957), Economics of the divisionalized firm, Journal of Business 30, 96-108.

Huizinga, H. and L. Leaven (2005), International profit shifting within European multinationals, Mimeo, Tilburg University.

Jacob, J. (1996), Taxes and transfer pricing: Income shifting and the volume of intrafirm transfers, Journal of Accounting Research 34, 301-312.

Kant, C. (1990), Multinational firms and government revenues, Journal of Public Economics 42, 135-147.

Lipponer, A. (2006), Microdatabase direct investment-MiDi. A brief guide, Bundesbank Working Paper, Frankfurt.

MacKie-Mason, J.K. (1990), Do taxes affect corporate financing decisions? Journal of Finance 45, 1471-1493.

Schjelderup, G. and L. Sørgard (1997), Transfer pricing as a strategic device for decentralized multinationals, International Tax and Public Finance 4, 277-290.

Swenson, D.L. (2001), Tax reforms and evidence of transfer pricing, National Tax Journal $54,7-25$.

Weichenrieder, A. (2006), Profit shifting in the EU: Evidence from Germany, Paper presented at the European tax policy forum conference 'The impact of corporation taxes across borders', London. 